\title{
PHAEOCHROMOCYTOMA IN CHILDREN
}

\author{
BY
}

\author{
J. INSLEY and W. C. SMALLWOOD \\ From The Children's Hospital, Birmingham
}

(RECEIVED FOR PUBliCATION AUGUST 13, 1962)

Tevetoğlu and Lee (1956) and Cone, Allen and Pearson (1957) together collected 46 cases of phaeochromocytoma occurring in children under the age of 14 years. Since then a further 12 cases have been reported (Robinson and Williams, 1956; Spencer, Wyatt and Chisholm, 1956; Shocket and Teloh, 1957; Higgins, 1957; Slocombe, 1957; Linke, Rosenthal and Kiefer, 1958; Galloway, Martens, Dimmette, Kenney and Cone, 1959; Greenberg and Gardner, 1959; Nikolaev and Belikhova, 1959; Harlem, 1960; Maclaurin and Arneil, 1961).

This paper describes four previously-unreported cases of phaeochromocytoma from the Birmingham Children's Hospital and includes also a review of other reported cases in children with regard to sex and age incidence, multiplicity and sites of tumours. The differential diagnosis is mentioned briefly. The investigations used in the diagnosis of phaeochromocytomas and their subsequent localization within the body are discussed in more detail. The danger to life of hypertensive crisis by the time the case reaches hospital care and the great value of 'rogitine' (phentolamine) in pre-operative management are emphasized. The monitoring of blood pressure and its control with phentolamine and noradrenaline during the operation for the removal of the tumour are described.

\section{Case Reports}

Case 1. A boy, aged $6 \frac{1}{2}$ years, the elder of two children, was admitted in 1937 without a definite diagnosis. For three and a half months increasing irritability and lassitude had been present, and for two months, nocturnal sweating, thirst and early morning sickness. During the two weeks before admission there was headache and for one week pallor and blueness of the limbs. His parents noticed that when excited his pupils became unusually dilated.

He was described as a well-developed boy, though his weight was $38 \mathrm{lb}$. $(17 \cdot 24 \mathrm{~kg}$.) [normal average $47 \mathrm{lb}$. $(21.32 \mathrm{~kg}$.)]. Blood pressure was $200 / 170 \mathrm{~mm}$. $\mathrm{Hg}$. The heart was not enlarged, but an apical systolic murmur was present. The fundi showed gross bilateral papilloedema, with star-shaped macular exudates. There was moderate albuminuria but no glycosuria. Blood urea $55 \mathrm{mg} . / 100 \mathrm{ml}$. Fasting blood sugar $132 \mathrm{mg} . /$ $100 \mathrm{ml}$.: 40 minutes after the administration of $50 \mathrm{~g}$. glucose by mouth the level rose to $226 \mathrm{mg} . / 100 \mathrm{ml}$., falling to $163 \mathrm{mg}$./100 ml. after two and a half hours.

Eight days after admission he developed generalized convulsions and died.

Autopsy revealed left ventricular hypertrophy. The renal cortices were injected. The right adrenal gland was enlarged by a well-encapsulated round tumour $2 \times 3.5 \times 4 \mathrm{~cm}$.

Microscopy showed the tumour to consist of nests of large cells separated by vascular fibrous trabeculae. Cells with two or three nuclei were common. There was abundant cytoplasm which was sometimes clear or vacuolated but more often granular. These granules impregnated well with silver, stained red with Heidenhain's aniline blue-azocarmine and brown with haematoxylin and eosin after mordanting in Muller's (bichromate) fluid.

The kidneys showed arterial and arteriolar hypertrophy.

Case 2. A boy, aged 9 years, was admitted in 1948 with a month's history of recurrent nausea, vomiting, headache and constipation. During the day before admission these symptoms had increased and he complained of abdominal pain.

He was thin, weight $47 \mathrm{lb}$. $(21 \cdot 32 \mathrm{~kg}$.) [normal average $59 \mathrm{lb}$. (26.76 kg.)], drowsy, uncooperative and dehydrated. Pulse rate $120 / \mathrm{min}$.; blood pressure $175 / 150$ $\mathrm{mm}$. Hg. Early papilloedema was present more in the left eye than in the right. There was heavy albuminuria but no glycosuria. Blood urea was $41 \mathrm{mg} . / 100 \mathrm{ml}$. The provisional diagnosis made on admission was chronic nephritis.

Two days after admission he lost consciousness and developed convulsive movements of the upper limbs, which later became generalized. The cerebrospinal fluid contained $70 \mathrm{mg} . / 100 \mathrm{ml}$. protein, but was otherwise normal. He died 12 hours after the onset of generalized convulsions.

Autopsy revealed an enlarged left ventricle and early atheroma of the ascending aorta. The right adrenal gland contained a well-encapsulated brown tumour $4 \times 1.8 \times 2.2 \mathrm{~cm}$. in size, weighing with the gland $22.4 \mathrm{~g}$. A similar but smaller tumour $2 \times 1.6 \times 1 \mathrm{~cm}$. in size was found in the left adrenal, weighing with the gland $9.3 \mathrm{~g}$. The brain was somewhat oedematous 
and a left temporo-parietal subdural haematoma was present.

Microscopy showed nests of large cells separated by thin vascular septa. The cytoplasm was in general finely granular with occasional vacuoles. The granules were brown in colour in haematoxylin and eosin sections after fixation in Orth's fluid. They impregnated poorly with silver. The tumours were well differentiated without evidence of anaplastic cell forms.

Kidney and other tissues showed marked arterial and arteriolar hypertrophy. There was atheromatous thickening of the aorta.

Case 3. A boy, aged $13 \frac{1}{2}$ years was admitted on November 2, 1960, with an 18-month history of attacks of pallor and sweating of increasing severity. For five months he had complained of recurrent left parietal headache, sometimes as often as twice a day and occurring at any time of day. His energy was unimpaired. He had vomited once, two weeks before admission.

He was pallid, small [height $54 \mathrm{in}$. $(137 \cdot 2 \mathrm{~cm}$.), average normal $60 \mathrm{in}$. $(152 \mathrm{~cm}$.)] and thin [weight $70 \mathrm{lb} .(31 \cdot 75$ kg.), average normal $88 \mathrm{lb}$. (32.92 kg.)] (Fig. 1a). Pulse rate $100 / \mathrm{min}$; blood pressure $180 / 140 \mathrm{~mm}$. $\mathrm{Hg}$. The heart was of normal size with an accentuated aortic second sound. The optic fundi showed well-marked papilloedema more on the left than on the right (Fig. 2). The grossly tortuous retinal arteries appeared to be in spasm, so that lengths of the vessels were seen only with difficulty. There were no exudates or haemorrhages. No abdominal masses were palpable. The provisional diagnosis on admission was phaeochromocytoma.

Radiographs of the chest revealed that the heart was not enlarged, but the left ventricle was prominent. An electrocardiogram showed left ventricular hypertrophy and strain. The urine contained $20 \mathrm{mg} . / 100 \mathrm{ml}$. of albumin but no sugar. A specific gravity of 1,022 was reached after a 12-hour fast. Blood urea $21 \mathrm{mg}$./ $100 \mathrm{ml}$. Creatinine clearance normal. Intravenous pyelogram was normal. Glucose tolerance test normal. An intravenous injection of $3 \mathrm{mg}$. of phentolamine produced a fall of blood pressure from 180/140 to $145 / 95 \mathrm{~mm}$. $\mathrm{Hg}$ within one minute. Four 24-hour collections of urine showed catecholamine excretions of $2,600,1,460,365$ and $3,686 \mu \mathrm{g}$. (upper limit of normal is $180 \mu \mathrm{g}$.$) .$

Five days after admission his blood pressure rose to 240/180 mm. Hg. Phentolamine was given by mouth pre-operatively, increasing from a dose of $25 \mathrm{mg}$. every four hours to $70 \mathrm{mg}$. every three hours. On this régime the blood pressure was maintained at a level of about $180 / 125 \mathrm{~mm}$. Hg without peaks of hypertension. Presacral air insufflation and contrast radiography carried out on the day before operation were unrewarding. Pre-operatively, on November 15, 1960, a cut-down intravenous infusion, using a wide-bore polythene canula, was set up in the antecubital fossa of the left arm. A $5 \%$ dextrose solution was dripped slowly to maintain patency. A second flask of $5 \%$ dextrose containing $8 \mathrm{mg}$. of noradrenaline per litre was connected to the first infusion so that release of a clip would immediately allow the noradrenaline solution to run into the

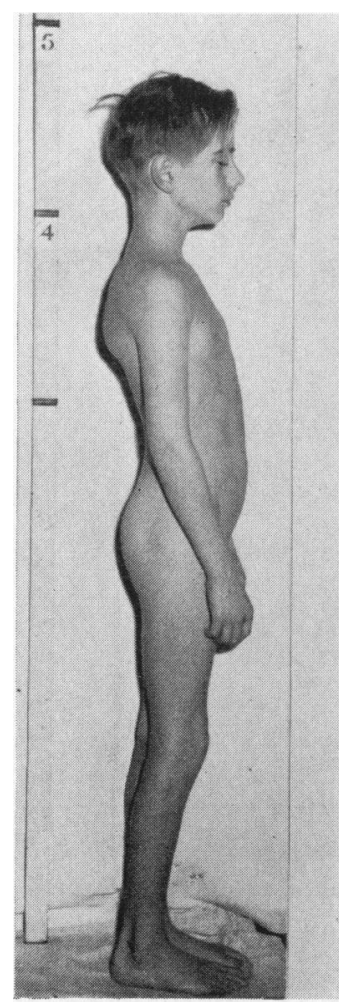

Fig. 1a.-Case 3.

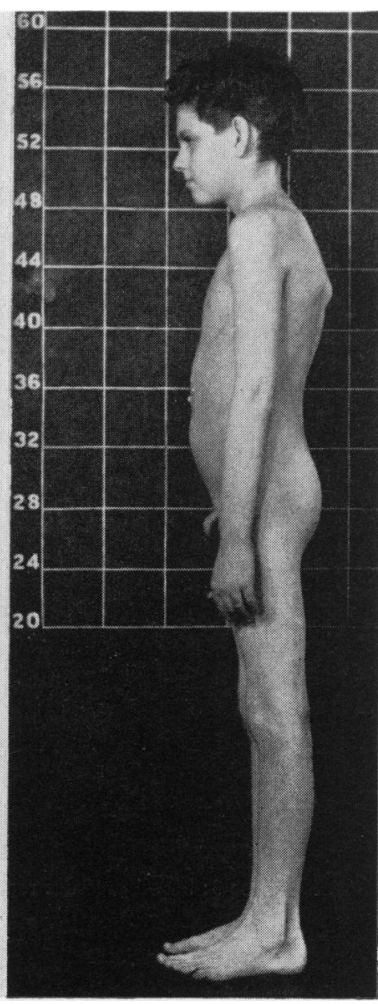

Fig. 1b.-Case 4. vein. Later, during the operation phentolamine was given intravenously in single doses by syringe and needle through the drip tubing. Apparatus for recording

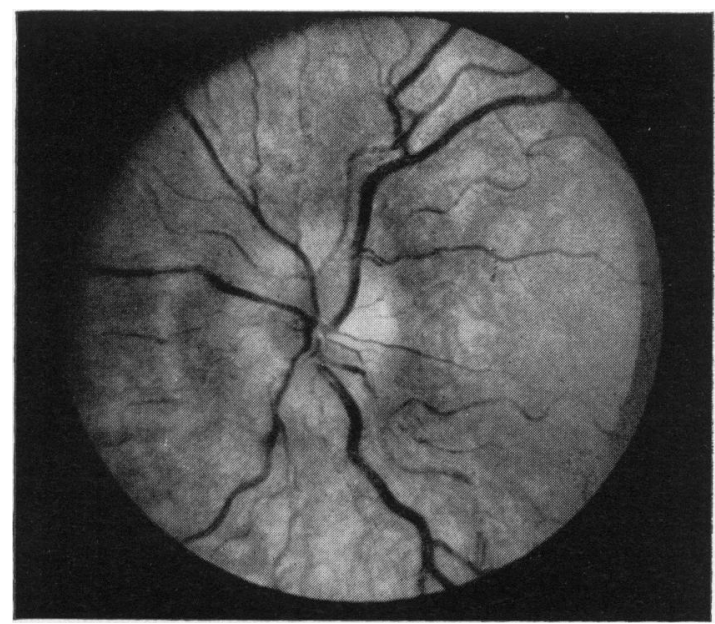

FIG. 2.-Case 3: left fundus showing papilloedema, distended veins and markedly irregular narrowed tortuous arteries. 


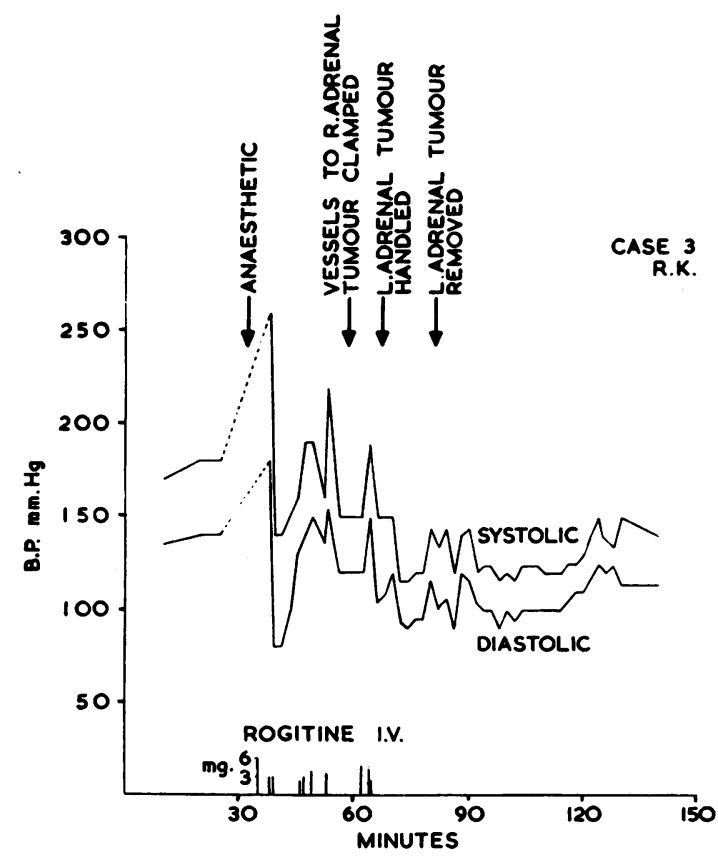

Fig. 3.-Case 3: blood pressure record and control during operation.

blood pressure by remote control during the operation was affixed to the other arm. It was found that one person was fully occupied taking readings of, and controlling, the blood pressure, while an assistant recorded the figures.

Pre-medication with atropine $0.4 \mathrm{mg}$. and 'omnopon' $7.5 \mathrm{mg}$. was followed by anaesthesia of pentothal, oxygen and curare. A rapid rise of blood pressure which occurred during the induction may have been due to the histamine-like action of curare enhancing the pressor response to noradrenaline.

The posterior abdominal wall was widely exposed by a midline anterior abdominal incision. Although the anatomy of the posterior abdominal wall was somewhat obscured by much unabsorbed air, two tumours, one in each adrenal gland, were identified with ease. Each was well encapsulated and was enucleated without difficulty with some adrenal cortex adhering. A left renal biopsy was taken. No other tumour masses were found.

The blood pressure was recorded at minute intervals throughout the operation (Fig. 3). Peaks of blood pressure were controlled with intermittent intravenous phentolamine and in all $29 \mathrm{mg}$. were used. There was a gradual fall of blood pressure during operation, but no sudden fall occurred when the tumours were removed or at any other time. Two pints of blood were transfused into a leg vein.

At the end of operation the blood pressure was $115 / 90 \mathrm{~mm}$. Hg. Frequent recordings were obtained during the next 48 hours. One week later it had risen to $145 / 110 \mathrm{~mm} . \mathrm{Hg}$, but over the next year it fell gradually to $110 / 90 \mathrm{~mm}$. $\mathrm{Hg}$. During this period the patient gained 3 in. $\left(7.62 \mathrm{~cm}\right.$.) in height and $7 \frac{1}{2} \mathrm{lb} .(3.4 \mathrm{~kg}$.) in weight. Papilloedema regressed, but marked tortuosity of the arteries remained. The urinary catecholamines were within normal limits five and a half months after operation.

Adrenal function, judged by 24-hour urinary excretion of 17-ketosteroids ( $7 \mathrm{mg}$.), 17-hydroxyketosteroids (5 mg.) and a Kepler 1 water load test, was normal after operation.

The adrenal tumours appeared almost identical, each being a firm ovoid mass with a maximum diameter of $2.5 \mathrm{~cm}$. The cut surfaces had a pale yellow appearance with small areas of haemorrhage and a few small cystic spaces.

They were examined both histologically and biochemically. The results of biological assays which were carried out by Dr. J. J. Brown of the Medical Unit, St. Mary's Hospital, London, and the biochemical investigations in our own laboratories are considered later.

Histologically the tumours were similar in appearance and were characteristic of phaeochromocytoma (see Fig. 5a). They showed broad interwoven bands separated by wide thin-walled anastomosing blood spaces. The shape of the cells varied, some being slender and fusiform, others fat and polygonal. The nuslei also varied and several were intensely basophilic and irregular in shape. Both tumours contained areas of necrosis and consequent cystic degeneration which appeared to be ischaemic in origin. Thrombosis was seen in adjacent sinusoids. The left adrenal vein lay between the tumour and the adrenal medulla and showed marked eccentric fibrous intimal thickening.

The renal biopsy showed evidence of mild hypertensive nephrosclerosis with medial hypertrophy of the small muscular arteries and slight thickening of the afferent arterioles. No hyaline or fibrinoid change was seen. Most glomeruli were normal, but some showed some thickening of Bowman's capsule and slight focal wrinkling and thickening of the capillary basement membrane.

Case 4. A boy aged $13 \frac{1}{2}$ years was admitted on January 24, 1961, with an 11-month history of early morning vomiting and headache, excessive sweating, tiredness and weakness. Three months before admission he became jaundiced with vomiting and abdominal pain from which he had largely recovered two weeks later, though he was left with some recurring abdominal pain. Four weeks before admission his vision deteriorated, especially in the right eye, so that he was no longer able to read. He was admitted with a diagnosis of malignant hypertension.

He was small [height $56 \frac{1}{2}$ in. $(143.5 \mathrm{~cm}$.), average normal $60 \mathrm{in} .(152 \mathrm{~cm}$.)] and thin [weight $67 \mathrm{lb} .(30.4 \mathrm{~kg}$.), average normal $89 \mathrm{lb}$. $(40.37 \mathrm{~kg}$.)] (see Fig. 1b). The skin was pale, cold and moist with bluish mottling of the forearms. Pulse 100/min.; blood pressure 220/170 $\mathrm{mm}$. Hg. There was evidence of slight left ventricular enlargement with a basal systolic murmur and a loud 
aortic second sound. No masses were palpable in the abdomen. Bilateral papilloedema which was more marked in the left eye than in the right was accompanied by venous engorgement, exudates and haemorrhages (Fig. 4). Visual acuity was right $6 / 9$, left $6 / 18$. Hb $114 \%$; W.B.C. $14,000 /$ c.mm. with $68 \%$ neutrophil polymorphs. Chest radiograph revealed that the heart was not enlarged in its transverse diameter, but the left ventricle and aorta were prominent. Urine on admission contained albumin $110 \mathrm{mg} . / 100 \mathrm{ml}$. and occasional red and white cells. After a period of bed-rest the urine became normal. Blood urea $36 \mathrm{mg} . / 100 \mathrm{ml}$. Creatinine clearance $52 \%$ of normal. Intravenous pyelogram normal. Following an intravenous injection of $3 \mathrm{mg}$. of phentolamine there was a fall of blood pressure from 190/155 to $120 / 90 \mathrm{~mm}$. Hg within one minute. A 24-hour urine collection contained $30,000 \mu \mathrm{g}$. catecholamines.

An attempt was made to localize the tumour by estimating the noradrenaline and adrenaline levels in the blood at various points in the inferior vena cava. A cardiac catheter was introduced into the left femoral vein in the groin. Specimens were collected at five levels, i.e. at the bifurcation of the common iliac vessels, opposite the lower border of L1, T12, T11 and in the right atrium. A short tributary, possibly the right

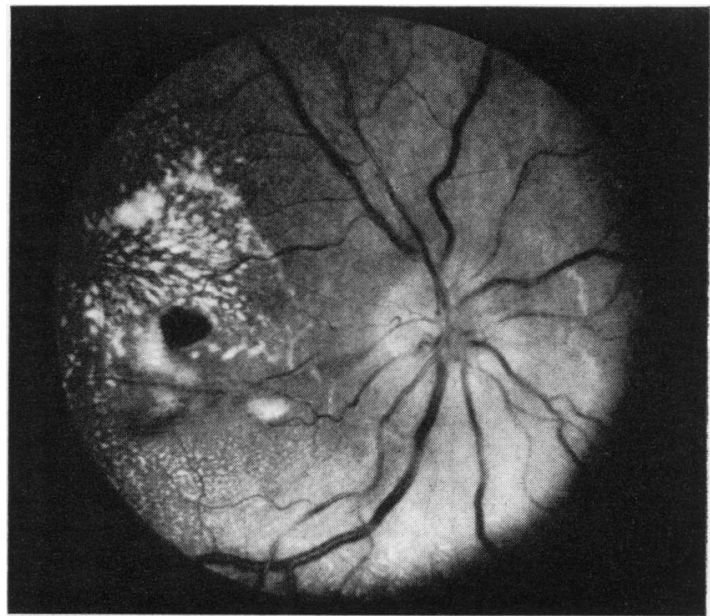

Fig. 4.-Case 4: left fundus showing papilloedema, macular exudates and haemorrhages, venous distension and arterial narrowing.

adrenal vein, was entered opposite the lower border of $\mathrm{T} 12$, and it was from here that the highest recorded

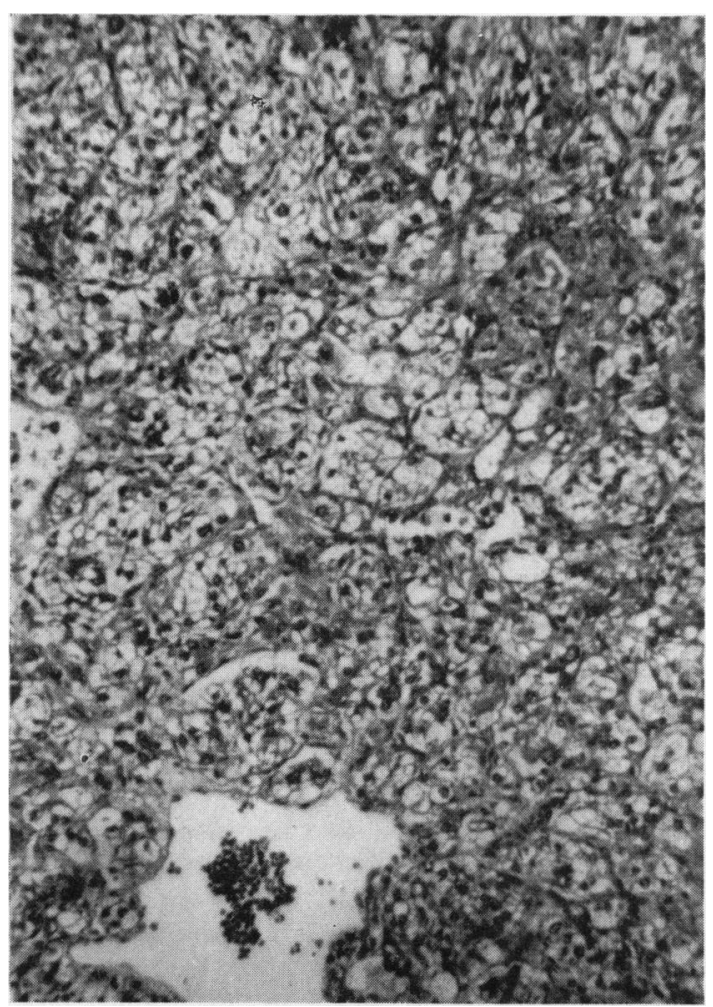

FIG. 5a.-Left adrenal tumour from Case 3, showing anastomosing cords of large vacuolated cells separated by sinusoidal blood spaces. (H. and E. $\times 55$.)

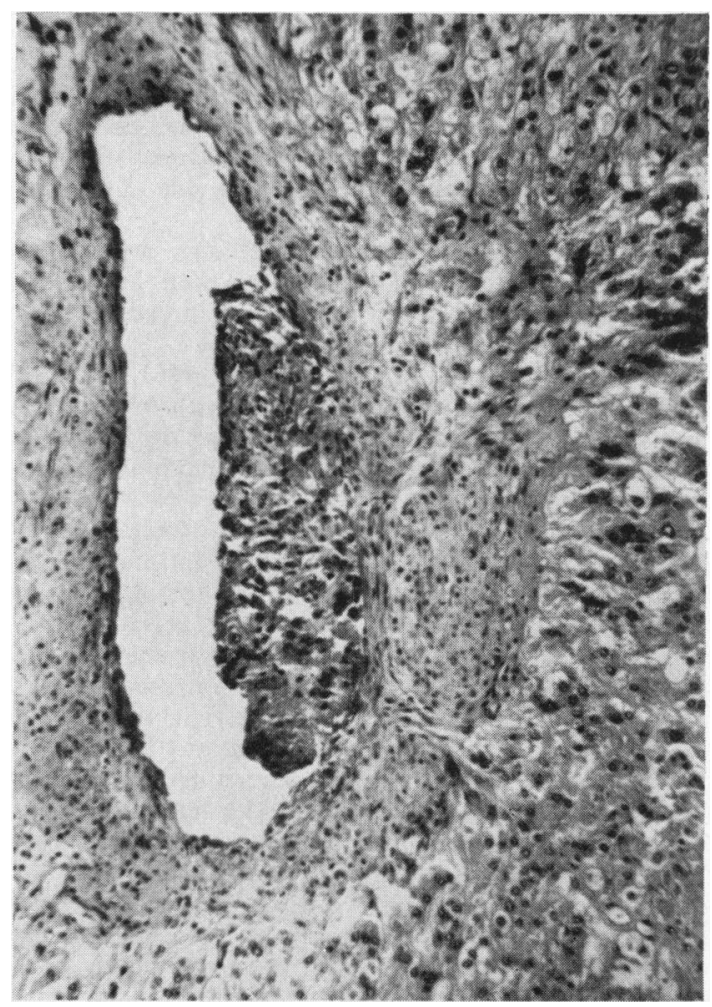

Fig. 5b.-Adrenal tumour from Case 4, showing an adrenal vein surrounded by growth and a plaque of tumour cells attached to the intima. (H. and E. $\times$ 55.) 


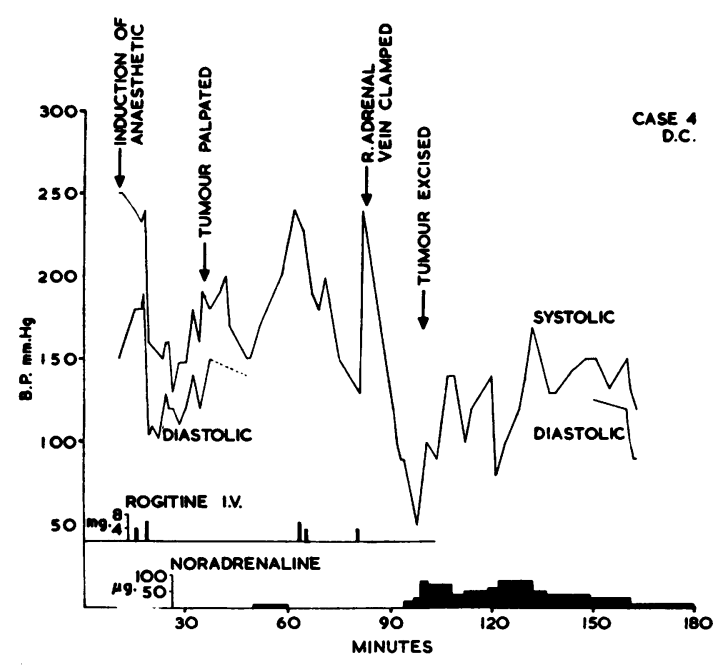

FIG. 6.-Case 4: control of blood pressure during operation.

level of pressor substances was obtained. Dr. J. J. Brown estimated by bioassay that this specimen contained the equivalent of $300 \mu \mathrm{g}$. noradrenaline/litre plasma. The ratio of biologically-assayed noradrenaline to adrenaline was about 10 to 1 . Since adrenaline is normally the major substance released into the adrenal vein, this result was interpreted as evidence of phaeochromocytoma draining into the right side of the cava at that level.

The use of oral phentolamine $10 \mathrm{mg}$. and $20 \mathrm{mg}$. alternately every two hours was followed by marked symptomatic improvement, the blood pressure falling from $240 / 190$ to $190 / 140 \mathrm{~mm}$. $\mathrm{Hg}$.

On the day of operation, February 9, 1961, while still in the ward, an intravenous infusion with $5 \%$ dextrose and a side drip of noradrenaline was set up in the arm as in Case 3, and arrangements were made to monitor the blood pressure.

Premedication was with papaveretum $10 \mathrm{mg}$., atropine $0.3 \mathrm{mg}$. and phentolamine $3 \mathrm{mg}$. intramuscularly. Anaesthesia was induced with pentothal, succinyl choline, gas and oxygen.

The posterior abdominal wall was examined through a midline anterior abdominal incision, and a hard vascular tumour which involved the right adrenal and passed behind the inferior vena cava was found. The liver and right kidney were mobilized and rotated forwards to facilitate its removal. The left adrenal was normal and no other tumour masses were seen. A renal biopsy was taken.

Peaks of blood pressure during the operation were controlled with intermittent intravenous phentolamine, $12 \mathrm{mg}$. in all being used. After the blood supply to the tumour had been clamped the systolic blood pressure fell rapidly from 240 to $50 \mathrm{~mm}$. $\mathrm{Hg}$ and was then restored to normal levels by a continuous infusion of noradrenaline (maximum was $0.04 \mathrm{mg}$. $/ \mathrm{min}$.). The blood pressure was monitored at one-minute intervals throughout the operation (Fig. 6). Shortly after the start of operation it became inaudible to auscultation and from then on systolic values were obtained only by palpation and at times with difficulty. The inferior vena cava was occluded during part of the operation and this may have affected the pulse. Four pints of blood were given.

The specimen consisted of a lobulated tumour $(5 \cdot 5 \times$ $4.5 \times 2.5 \mathrm{~cm}$.) attached to the right adrenal and this was examined pathologically and biochemically.

The fibrous capsule was extremely vascular and thick. It gave rise to a few trabeculae passing into the substance of the tumour. Histologically the tumour showed a characteristic structure of alveolar cords separated by thin-walled sinusoids. Many cells had a large amount of clear cytoplasm, and small droplets of lipid and glycogen were seen in the cytoplasm of most. The nuclei were generally round and open and double nuclei were common. Multi-nucleated cells were also seen and in some areas there was intense basophilia mainly due to mitotic prophase activity. The capsule and trabeculae were not invaded by the tumour, but a vein within the substance of the tumour showed a plaque of tumour cells attached to the intima (Fig. 5b). This intravenous growth was vascularized by capillaries and had evidently been present for some time. Several vessels in the capsule showed marked endarteritis obliterans and in one there was fibrinoid necrosis of the wall with a granulomatous cellular reaction. The appearances were regarded as those of malignancy.

In the kidney there was medial hypertrophy of arteries and arterioles and fibroelastic thickening of the intima in the larger arteries. Most glomeruli were normal, but one showed an epithelial crescent and in a few there was slight thickening of Bowman's capsule. The basement membrane of the capillary tufts was normal as well as the tubules. The appearances were those of hypertensive arterial hypertrophy.

The blood pressure was $125 / 75 \mathrm{~mm}$. Hg 24 hours after operation, and the noradrenaline drip was discontinued. Frequent blood pressure recordings were continued for a further day. One year later the blood pressure was $135 / 75 \mathrm{~mm}$. $\mathrm{Hg}$ and the boy had gained $2 \frac{1}{4}$ in. $(5 \cdot 72 \mathrm{~cm}$.) in height and $45 \mathrm{lb} .(20 \cdot 41 \mathrm{~kg}$.) in weight. His visual acuity was: right $6 / 5$, left $6 / 9$. A few small hard exudates remained in both macular areas and there was a little residual blurring of the margins of the discs. Urinary catecholamine estimations carried out postoperatively and again 20 months later were normal. The urine was free of albumin. Creatinine clearance was $91 \%$ of normal.

\section{Methods of Estimation and Chromatography of Catecholamines in Urine and Tumour Tissue}

The screening test for phaeochromocytoma which is now commonly used was first described by Hingerty (1957) and is a fairly quick and simple method of assaying catecholamines in urine. These are mainly noradrenaline and adrenaline. Certain of their precursors and derivatives are included in the measurement. The result is expressed in $\mu \mathrm{g}$. $/ 24$ hours and in normal persons has 
TABLE 1

\begin{tabular}{|c|c|c|c|c|c|c|c|c|}
\hline & & & \multirow{2}{*}{$\begin{array}{c}\text { Noradrenaline } \\
(\mu \mathrm{g} . / 24 \mathrm{hrs})\end{array}$} & \multirow{2}{*}{$\begin{array}{c}\text { Hydroxytyramine } \\
\text { ( } \mu \mathrm{g} . / 24 \mathrm{hrs})\end{array}$} & \multirow{2}{*}{$\begin{array}{l}\text { Adrenaline } \\
\text { ( } \mu \mathrm{g} . / 24 \mathrm{hrs})\end{array}$} & \multicolumn{2}{|c|}{$\begin{array}{c}\text { Total Catecholamines } \\
(\mu \mathrm{g} . / 24 \mathrm{hrs})\end{array}$} & \multirow{2}{*}{$\begin{array}{l}\text { Vanilyl } \\
\text { Mandelic } \\
\text { Acid }\end{array}$} \\
\hline & & & & & & $\begin{array}{c}\text { Hingerty } \\
\text { Test }\end{array}$ & $\underset{\text { Aiological }}{\text { Assay }}$ & \\
\hline $\begin{array}{l}\text { CASE } 3 \\
\text { Pre-op. urine: } \\
\text { Nov. 11-12, } 1960 \\
\text { Nov. 12-13 } \\
\text { Nov. 13-14 }\end{array}$ & $\begin{array}{l} \\
\cdots \\
\cdots\end{array}$ & $\begin{array}{l}\cdots \\
\cdots \\
\cdots\end{array}$ & $\begin{array}{c}\text { Not detected } \\
70\end{array}$ & $\begin{array}{l}195 \\
260\end{array}$ & $\begin{array}{r}65 \\
160\end{array}$ & $\begin{array}{c}\text { Approx. } 1,460 \\
\text { Approx. } 365 \\
\text { Approx. } 3,686\end{array}$ & 600 & Greatly increased \\
\hline $\begin{array}{l}\text { Post-op. urine: } \\
\text { Nov. 17-18 } \\
\text { Nov. 18-19 } \\
\text { Nov. 21-22 } \\
\text { Nov. 22-23 }\end{array}$ & $\begin{array}{l}\cdots \\
\cdots \\
\cdots\end{array}$ & \begin{tabular}{l|}
$\cdots$ \\
$\cdots$ \\
$\cdots$
\end{tabular} & Not detected & 18 & 28 & $\begin{array}{c}\text { High } \\
\text { Slightly greater } \\
\text { than normal } \\
\text { Normal } \\
\text { Normal }\end{array}$ & & Normal \\
\hline \multicolumn{2}{|c|}{$\begin{array}{l}\text { Right adrenal tumour } \\
\text { ( } \mu \text { g./g., wet weight) } \\
\text { Left adrenal tumour } \\
\text { ( } \mu \mathrm{g} . / \mathrm{g} ., \text { wet weight) }\end{array}$} & $\cdots$ & & $\begin{array}{l}178 \\
820\end{array}$ & & & 400 & \\
\hline $\begin{array}{l}\text { CASE } 4 \\
\text { Pre-op. urine: } \\
\text { Jan. 26-27, } 1961 \\
\text { Jan. 28-29 .. } \\
\text { Jan. 29-30 .. }\end{array}$ & $\begin{array}{l} \\
\cdots \\
\cdots\end{array}$ & $\begin{array}{l}\cdots \\
\cdots \\
\cdots\end{array}$ & $\begin{array}{l}2,610 \\
6,550\end{array}$ & $\begin{array}{l}2,610 \\
6,550\end{array}$ & $\begin{array}{r}1,044 \\
984\end{array}$ & Approx. 30,000 & & Greatly increased \\
\hline $\begin{array}{l}\text { Post-op. urine: } \\
\text { Feb. 11-12 } \\
\text { Feb. 12-13 }\end{array}$ & $\begin{array}{l}\cdots \\
\cdots\end{array}$ & $\begin{array}{l}\ldots \\
\cdots\end{array}$ & 36 & 70 & $\begin{array}{l}\text { Not easily } \\
\text { estimated }\end{array}$ & $\begin{array}{l}\text { Normal } \\
\text { Normal }\end{array}$ & & Normal \\
\hline Adrenal tumour & $\cdots$ & $\cdots$ & & $\begin{array}{l}3,100 \mu \mathrm{g} . / \mathrm{g} . \\
\text { (wet weight) }\end{array}$ & & & & \\
\hline
\end{tabular}

an upper limit of $180 \mu \mathrm{g}$. Accurate quantitative estimation of the individual catecholamines in tissues and fluid demands the use of costly fluorimetric equipment, though a reasonably true assessment can be made by comparing the intensity of ultraviolet fluorescence of the buffered oxidation products of test and standard substances after separation of the former by paper chromatography (McMillan, 1957). The results obtained by using this last method on urines and tumours of Cases 3 and 4 are shown in Table 1 and some of these are compared with results obtained by Dr. J. J. Brown using a biological assay.

Case 3. The urine collected pre-operatively but examined by chromatography some weeks later showed hydroxytyramine as the most prominent fraction. Adrenaline output was increased in two specimens examined. Noradrenaline was present in normal amounts in one and could not be detected in a second specimen. Dihydroxyphenylalanine (DOPA) was not detected in either urine. Because of the interval between collection and testing, the accuracy of the result was questioned. However, estimations made more recently on specimens from other patients before and after storage suggest that the results obtained in Case 3 were probably correct. The output of 4-hydroxy 3-methoxy mandelic acid (H.M.M.A. previously referred to as V.M.A. or vanilyl mandelic acid) in one specimen examined by the method of Robinson, Ratcliffe and Smith (1959) was greatly increased. The 24-hour output of pressor amines estimated biologically as noradrenaline was $600 \mu \mathrm{g}$. (Table 1) and includes substances such as hydroxytyramine which were not differentiated from noradrenaline by this method. The ratio of noradrenaline to adrenaline by this method was approximately $4: 1$. Examination of urine collected three days after operation showed that the hydroxytyramine, adrenaline and H.M.M.A. content were normal. Noradrenaline was not present in excess.

The right and left adrenal tumours each contained approximately $0.4 \mathrm{mg}$. per g. (wet weight) of pressor amines estimated biologically as noradrenaline. Using the chromatographic method mentioned earlier hydroxytyramine was the only pressor substance isolated from the two tumours. Yields of 178 and $820 \mu \mathrm{g}$. hydroxytyramine/g. wet tissue were obtained from the right and left tumours respectively.

Case 4. Chromatography of the urine before operation revealed large quantities of adrenaline and even larger quantities of hydroxytyramine and noradrenaline (Table 1). H.M.M.A. was excreted in large quantities. Dihydroxyphenylacetic acid and dihydroxyphenyl serine were detected. DOPA was not detected. Two slowrunning components which were present were not identified. In the urine after operation normal amounts of noradrenaline and hydroxytyramine were present. DOPA and an unidentified fast-running component were present in small quantities. The excretion of H.M.M.A. was normal. Adrenaline was not found.

Chromatographic assay of the catecholamines in the tumour removed showed a very high concentration of 


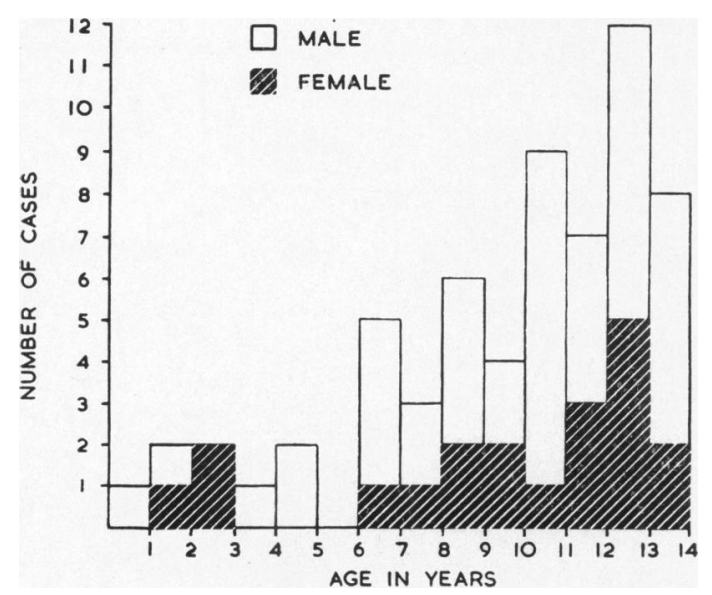

Fig. 7.-Age and sex incidence of phaeochromocytoma in 62 children.

hydroxytyramine, but no adrenaline or noradrenaline. There was also a fast-running component thought to be isopropyl noradrenaline.

TABLE 2

SITES OF 80 TUMOURS IN 60 CASES OF PHAEOCHROMOCYTOMA UNDER THE AGE OF 14 YEARS

\begin{tabular}{|c|c|c|}
\hline Site & $\begin{array}{l}\text { Number } \\
\text { of } \\
\text { Cases }\end{array}$ & Reference \\
\hline $\begin{array}{l}\text { Left adrenal alone } \\
\text { With a } 2 \text { nd tumour in front } \\
\text { of left adrenal }\end{array}$ & $\begin{array}{r}13 \\
1\end{array}$ & Snyder and Vick, 1947 \\
\hline $\begin{array}{l}\text { Right adrenal alone } \\
\text { With second tumour in neck } \\
\text { With second tumour at aortic } \\
\text { bifurcation } \\
\text { With second tumour on } \\
\text { anterior surface of left } \\
\text { kidney } \ldots \\
\text {. . }\end{array}$ & $\begin{array}{r}22 \\
1\end{array}$ & $\begin{array}{l}\text { Cone et al., 1957; } \\
\text { Cone, 1958 } \\
\text { Cone et al., } 1957 \\
\text { Schleisner, } 1954\end{array}$ \\
\hline $\begin{array}{l}\text { Both adrenals alone } \\
\text { With third tumour in thorax } \\
\text { With third tumour at aortic } \\
\text { bifurcation } \\
\text { With third tumour para- } \\
\text { vertebral } \ldots \text {.. }\end{array}$ & $\begin{array}{r}10 \\
1 \\
1 \\
1\end{array}$ & $\begin{array}{l}\text { Cone et al., } 1957 \\
\text { Hubble, } 1951 \\
\text { Galloway et al., } 1959\end{array}$ \\
\hline $\begin{array}{c}\begin{array}{c}\text { Intra-abdominal but extra } \\
\text { adrenal: } \\
\text { Aortic bifurcation } \ldots\end{array} \\
\text { Obstructing left ureter }\end{array}$ & 3 & $\begin{array}{l}\text { Snyder and Vick, } 1947 \\
\text { Cahill, 1948 } \\
\text { Shocket and Teloh, } 1957 \\
\text { Harlem, } 1960 \\
\text { Maclaurin and Arneil, } \\
\quad 1961\end{array}$ \\
\hline 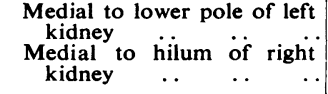 & $\begin{array}{l}1 \\
1\end{array}$ & $\begin{array}{l}\text { Iseri, Henderson and } \\
\text { Derr, } 1951 \\
\text { Cahill, } 1948\end{array}$ \\
\hline In left psoas muscle... & 1 & $\begin{array}{l}\text { Robinson and Williams, } \\
1956\end{array}$ \\
\hline
\end{tabular}

In the case described by Soffer and Gabrilove (1951) and the case described by Faber (1951), the sites of the tumours were not mentioned.

\section{Discussion}

The four cases described here form a substantial addition to the number of recorded cases of phaeochromocytoma diagnosed in childhood and bring the total to 62. Fig. 7 shows the higher incidence of the disorder in males and in the later years of childhood. Many recorded cases have had more than one tumour and this occurs more commonly in children than in adults. Table 2 records the sites of 80 tumours in 60 of the cases described, including our own. It has not been possible to include in this analysis all the cases reported.

It will be noted that in every one there was at least one tumour within the posterior abdomen and that in only two was there a second or third tumour outside the posterior abdominal wall, namely, one in the neck and one in the thorax. The importance of this distribution of the tumour masses largely within the abdomen is considered later in relation to pre-operative investigation and operative surgical approach.

In all the four cases described here, hypertension was sustained and this is usual in childhood. In only one was the correct diagnosis suggested at the time of the child's first attendance as an out patient. The bedside differential diagnosis from conditions such as acute and chronic nephritis, chronic pyelonephritis, unilateral kidney disease with hypertension, cerebral tumour, chronic meningitis, thyrotoxicosis, pink disease and lead poisoning may be difficult. The fact that the taking of blood pressure readings routinely is performed less commonly in children than in adults may delay making a diagnosis.

Once suspected, the diagnosis of phaeochromocytoma tissue in some part of the body is confirmed by carrying out certain tests, and these are more likely to yield positive evidence when hypertension is continuous. Of these tests the oldest, i.e. giving a dose of $3 \mathrm{mg}$. of phentolamine intravenously in Cases 3 and 4 , produced a fall greater than $35 / 25$ $\mathrm{mm}$. $\mathrm{Hg}$ in systolic/diastolic pressures within two minutes, which is commonly regarded as diagnostic (Gifford, Roth and Kvale, 1952). In Case 3 the test was performed at a time when phenobarbitone was being used as a sedative. False positive reactions have been reported in hypertensive subjects receiving phenobarbitone. False positive results have also been noted in uraemic patients and in some cases of hypertension not due to phaeochromocytoma (Roth, 1951; Gifford et al., 1952; Emlet, Grimson, Bell and Orgain, 1951; Ross, 1954; Bernstein and Rosenberg, 1954). False negative results are less commonly recorded (Euler, Lund, Olsson and Sandblom, 1953). The difficulty with 
the phentolamine test is that too many patients with hypertension show a fall, and it is not very clear what level of fall should be regarded as diagnostic. A more certain method of establishing a diagnosis of phaeochromocytoma is the demonstration of an excess of catecholamines in a 24-hour specimen of urine, and this was done in Cases 3 and 4 . However, some patients with infrequent or mild attacks of hypertension may excrete quantities of catecholamines that are within normal limits (Litchfield and Peart, 1956), and so it is possible that the estimation of 4-hydroxy 3-methoxy mandelic acid (H.M.M.A.) excreted in a four-hour specimen of urine may be a more reliable test (White, Handler, Smith and Stetten, 1959). H.M.M.A. is the main end-product of the metabolism of adrenaline and noradrenaline within the body. It is normally present in the urine in about 30 times the concentration of adrenaline and noradrenaline and is excreted in high concentrations by individuals with phaeochromocytoma. It remains to be proved that in the mild type of case mentioned above the excretion of this metabolic product is outside the normal limits. Further, in tumours that secrete mainly adrenaline, it is quite possible for them to produce marked symptoms with an excretion of total catecholamines in the urine, which is within normal limits. This makes the differentiation of adrenaline in the urine a matter of importance. This can be done readily biologically (Hamilton, Litchfield, Peart and Sowry, 1953) and less readily chemically.

We are impressed by the deaths from hypertensive encephalopathy in two of our cases, the one two days, the other eight days, after admission to hospital and by the severe degree of illness in Case 4 of the series at the time of his admission and for many days subsequently. The pre-operative readings of blood pressure in Case 3 of as high as $180 \mathrm{~mm} . \mathrm{Hg}$ diastolic were a cause for concern. Some of these peaks of hypertension were associated with procedures such as presacral air insufflation and later the induction of anaesthesia at the time of operation. Moore and Shumacker (1956) commented on a high mortality rate of $54 \%$ due mainly to the failure to combat adrenaline intoxication before operation and the lack of awareness of the relative frequency of extra adrenal and multiple tumours. It seems that by the time the symptomatology of the disorder is sufficiently well established to have brought the child to hospital the immediate risk to life is considerable and that physical and emotional traumata connected with in-patient pre-operative investigation and care may be critical. The use during this period of phentolamine given regularly by mouth and intra- venously at times of crisis was impressive, and may well have been an important factor in bringing Cases 3 and 4 safely to operation.

Once the presence in the body of phaeochromocytoma tissue has been established its localization pre-operatively has been the subject of various manoeuvres. It is seldom that the tumours are palpable and the effect on the hypertension of manual palpation of various quarters of the abdomen and loin has little to recommend it. Pyelography is unlikely to show any change in the position of a kidney unless the tumours are suprarenal and large or are obstructing the ureter (Harlem, 1960; Maclaurin and Arneil, 1961). Intravenous pyelography in our cases was unrevealing. Retrograde aortography has been used, but in adults has sometimes been followed by haemorrhage into the tumour and death (Saltz, Luttwak, Schwartz and Goldberg, 1956; Lopez, 1958). The presacral introduction of oxygen or air for contrast radiography of the posterior abdominal wall has been used more widely. It was employed in Case 3 and gave no indication of the two adrenal tumours that were found subsequently at operation. Instead, the residual gas present in the tissues of the posterior abdominal wall at operation on the following day obscured somewhat the anatomy of the area and rendered a little more difficult the recognition of the tumour masses. The procedure is not without risk from air embolism and hypertensive crisis. Intravenous phentolamine was necessary to lower the dangerously high blood pressure that occurred when Case 3 was investigated in this way. The more elaborate method used in Case 4, namely catheterization of the inferior vena cava, was first practised by Euler (Euler, Gemzell, Ström and Westman, 1955). The result obtained in his case was misleading because of the abnormal venous drainage of the affected adrenal gland. The method is dependent on the availability of facilities for the estimation of adrenaline and noradrenaline in blood and has the objections connected with catheterization of the inferior vena cava and the necessary radiographic control. In Case 4 the method provided evidence that suggested that the outflow of secretion into the cava was at the level of the vein from the right adrenal gland. Whether attempts such as these to localize the tumour pre-operatively are necessary or desirable is questioned. Reference has already been made to the danger to life of a phaeochromocytoma by the time the patient reaches hospital and the possible risk of physical and emotional trauma in promoting hypertensive crises. The data analysed in Table 2 suggest that in childhood at least one tumour will be found on the 
posterior abdominal wall and that the chances of there being a second or third tumour in any other part of the body are small. The relatively large numbers of cases with more than one tumour within the abdomen are also shown in Table 2. The need for a full exploration of the whole area in which the tumour or tumours may be expected, namely the posterior abdominal wall, is clear. This is best effected through an anterior transperitoneal approach provided by wide incision of the anterior abdominal wall. The fact that these subjects commonly have little body fat facilitates the exploration. In the two cases reported here which reached operation little difficulty was found in locating the tumours at operation even though in Case 3 air insufflation had obscured somewhat the anatomy of the posterior abdominal wall.

The minute-by-minute monitoring of blood pressure throughout operation and the control of blood pressure by intravenous phentolamine and a noradrenaline drip are recorded in the descriptions of Cases 3 and 4 . It fully occupied two persons. The occurrence of an untoward rise in blood pressure when the tumour is handled and of still more dangerous falls in blood pressure when the tumour is removed or the vessels first clamped is well recognized. In Cases 3 and 4 the most alarming hypertension occurred during the induction of anaesthesia. Only in Case 4 was there any serious hypotension when the tumour was removed.

Deaths due to hypotension in association with the sudden cutting off of amines secreted from the tumour still occur at the time of operation. Cases of phaeochromocytoma may also present with profound hypotension or with hypotensive attacks quite apart from operation. The difficulty in diagnosis in such cases has been emphasized recently by Leather, Shaw, Cates and Milnes Walker (1962) who refer to the published material on this subject and discuss the possible mechanism. In a personal communication, Professor Peart has recommended the use of dibenzaline orally in doses $10-20 \mathrm{mg}$. three times daily in the pre-operative control of adult patients with phaeochromocytoma. He suggests that the use of this drug in controlling hypertension pre-operatively may lessen the risk of hypotensive crisis at the time of operation.

The rapid regression of symptoms and signs in the patients treated surgically is in accord with the general experience. The gain in weight may be regarded as a result of return to normal of basal metabolism. It is debatable whether or not the early changes of arterial hypertension seen in biopsy specimens of the kidney taken at operation are reversible. The microscopy of the tumour removed from Case 4 suggests that it was malignant. However, the difficulty about diagnosis of a malignant phaeochromocytoma is that many of these tumours that subsequently turn out to be benign have cells within the lumen of the vein. The problem has been well reviewed by Kennedy, Symington and Woodger (1961).

\section{Summary}

Four previously-unreported cases of phaeochromocytoma in children are described. Of these, two were successfully treated surgically, two died in hypertensive crisis and one was histologically malignant.

In reviewing all cases reported in children (62 in all) 62 have been analysed regarding age and sex, 60 regarding site and multiplicity of tumours.

Methods used in diagnosing and localizing phaeochromocytoma are described.

Once diagnosed, the desirability of undertaking full surgical exploration of the posterior abdominal wall through an anterior approach without any pre-operative attempt to localize the tumour or tumours is discussed.

The danger to life once the case has reached hospital and the great value of phentolamine preoperatively and of phentolamine and noradrenaline during operation are noted.

We are grateful to Dr. B. D. Bower for permission to report Case 4, and also to Mr. A. Gourevitch, consultant surgeon, and Dr. R. Lee, consultant anaesthetist, who were responsible for the successful operations in Cases 3 and 4 . It is a pleasure also to acknowledge our gratitude to Professor W. S. Peart and Dr. J. J. Brown, of the Medical Unit, St. Mary's Hospital, London, for all their help in the investigation of Case 4 and the studies undertaken on tumours and fluids in Cases 3 and 4. We are indebted to Professor Peart for his criticisms of the text, and for a number of personal communications from which we have quoted.

We are grateful also to the late Mr. H. Salt and to Miss P. A. M. Hughes of the biochemistry department of our hospital for the chromatographic and biochemical studies and to them as well as to Mr. T. P. Whitehead for their help in preparing the biochemical text. We would like to thank Dr. A. H. Cameron for the histological reports and photomicrographs; Dr. R. Astley for the radiodiagnostic assistance; Mr. L. P. Jameson Evans for the use of the fundal photographs, and Dr. C. R. Kanagasundaram for taking them, and also to Mr. W. J. Hurt for the clinical photographs.

\section{REFERENCES}

Bernstein, D. E. and Rosenberg, M. L. (1954). False positive regitine tests; report of 2 cases. Stanf. med. Bull., 12, 124.

Cahill, G. F. (1948). Pheochromocytomas. J. Amer. med. Ass., $138,180$.

Cone, T. E., Jr. (1958). Recurrent pheochromocytoma; report of a case in a previously treated child. Pediatrics, 21, 994. Allen, M. S. and Pearson, H. A. (1957). Pheochromocytoma in children. Report of three familial cases in two unrelated families. ibid., 19, 44. 
Emlet, J. R., Grimson, K. S., Bell, D. M. and Orgain, E. S. (1951.) Use of piperoxan and regitine as routine tests in patients with hypertension. J. Amer. med. Ass., 146, 1383.

Euler, U. S. von, Gemzell, C. A., Ström, G. and Westman, A. (1955). Report of a case of pheochromocytoma, with special regard to preoperative diagnostic problems. Acta med. scand., 153, 127. to preoperative diagnostic problems. Acta med. scand., 153, 127. and adrenaline in blood and urine in a case of phaeochromocytoma. Scand. J. clin. Lab. Invest., 5, 122.

Faber M. (1951). Benzodioxan test in pheochromocytoma. Ugeskr. Laeg., 113, 413.

Galloway, C. B., Martens, V. E., Dimmette, R. M., Kenney, E. C. and Cone, T. E. (1959). Hypertension and weight loss in childhood.' U.S. armed Forces med. J., 10, 69.

Gifford, R. W., Roth, G. M. and Kvale, W. F. (1952). Evaluation of a new adrenolytic drug (Regitine) as a test for pheochromocytoma. J. Amer. med. Ass., 149, 1628.

Greenberg, R. E. and Gardner, L. I. (1959). Pheochromocytoma in father and son; report of the eighth known affected kindred. J. clin. Endocr., 19, 351.

Hamilton, M., Litchfield, J. W., Peart, W. S. and Sowry, G. S. C. (1953). Phaeochromocytoma. Brit. Heart J., 15, 241.

Harlem, O. K. (1960). Pheochromocytoma with secondary pyelonephritis. J. Pediat., 57, 225.

Higgins, F. E. (1957). Malignant hypertension due to phaeochromocytoma in a child. Arch. Dis. Childh., 32, 240.

Hingerty, D. (1957). Thirty-minute screening test for phaeochromocytoma. Lancet, 1, 766.

Hubble, D. V. (1951). Phaeochromocytoma in children. Arch. Dis. Childh, 26, 340.

Iseri, L. T., Henderson, H. W. and Derr, J. W. (1951). Use of adrenolytic drug, regitine, in pheochromocytoma. Amer. Heart J., 42, 129.

Kennedy, J. S., Symington, T. and Woodger, B. A. (1961). Clinical and histochemical observations in benign and malignant phaeochromocytoma. J. Path. Bact., 81, 409.

Leather, H. M., Shaw, D. B., Cates, J. E. and Milnes Walker, R. (1962). Six cases of phaeochromocytoma with unusual clinical manifestations. Brit. med. J., 1, 1373.

Litchfield, J. W. and Peart, W. S. (1956). Phaeochromocytoma with normal excretion of adrenaline and noradrenaline. Lancet, 2, 1283.

Linke, C. A., Rosenthal, I. and Kiefer, J. H. (1958). Bilateral pheochromocytoma in a 12-year-old boy. J. Urol. (Baltimore), 79, 781.
Lopez, J. F. (1958). Phaeochromocytoma of the adrenal gland with granulosa cell tumor and neurofibromatosis: report of a case with fatal outcome following abdominal aortography. Ann. intern. Med., 48, 187.

Maclaurin, J. C. and Arneil, G. C. (1961). Phaeochromocytoma causing ureteric obstruction in a child. Lancet, 1, 426.

McMillan, M. (1957). Urinary excretion of individual catechol derivatives. ibid., 1, 715 .

Moore, T.C. and Shumacker, H. B., Jr. (1956). Adrenalin producing tumors in childhood. Ann. Surg., 143, 256.

Nikolaev, O. V. and Belikhova, E. L. (1959). A case of phaeochromocytoma in a child. (In Russian.) Probl. éndokr. Gormonoter, 5, No. 1, p. 92.

Robinson, M. J. and Williams, A. (1956). Clinical and pathological details of two cases of phaeochromocytoma in childhood. Arch. Dis. Childh., 31, 69.

Robinson, R., Ratcliffe, J. and Smith, P. (1959) A screening test for phaeochromocytoma. J. clin. Path., 12, 541

Ross, R. D. (1954). False-positive reaction to the regitine test for pheochromocytoma: report of a case. Ann. intern. Med., 41, 1061 .

Roth, G. (1951). In discussion. Current methods of diagnosis of pheochromocytoma. J. Amer. med. Ass., 145, 884.

Saltz, N. J., Luttwak, E. M., Schwartz, A. and Goldberg, G. M. (1956). Danger of aortography in the localization of pheochromocytoma. Ann. Surg., 144, 118

Schleisner, P. (1954). Bilateral phaeochromocytoma in a child the differential diagnosis from nephritis. Dan. med. Bull. 1,142 .

Shocket, E. and Teloh, H. A. (1957). Aganglionic megacolon pheochromocytoma, megaloureter and neurofibroma. $A \cdot M \cdot A$. J. Dis. Child. 94, 185.

Slocombe, G. (1957). Pheochromocytoma in a boy aged ten years. ibid., $93,530$.

Snyder, C. H. and Vick, E. H. (1947). Hypertension in children caused by pheochromocytoma. Report of three cases and review of the literature. ibid., 73, 581 .

Soffer, L. J. and Gabrilove, J. L. (1951). Diseases of the Endocrine Glands, p. 387. Lea and Febiger, Philadelphia.

Spencer, B. J., Wyatt, O. S. and Chisholm, T. C. (1956). Pheochromocytoma in a 7-year-old girl; report of successful removal. Minn. Med., 39, 220.

Tevetoğlu, F. and Lee, C. H. (1956). Adrenal rheochromocytoma simulating diabetes insipidus; report of case and review of other simulating diabetes insipidus; report of case and review
pediatric cases. A.M.A. Amer. J. Dis. Child., 91, 365.

White, A., Handler, P., Smith, E. L. and Stetten, DeWitt (1959). Principles of Biochemistry, 2nd ed., p. 910. McGraw-Hill, New York. 